\section{Internal fight threatens future of Strangeways laboratory in Britain}

London. The future of an 81-year-old private British laboratory carrying out world-class research on connective tissue has been jeopardized by a disagreement between senior scientific staff and trustees over a planned

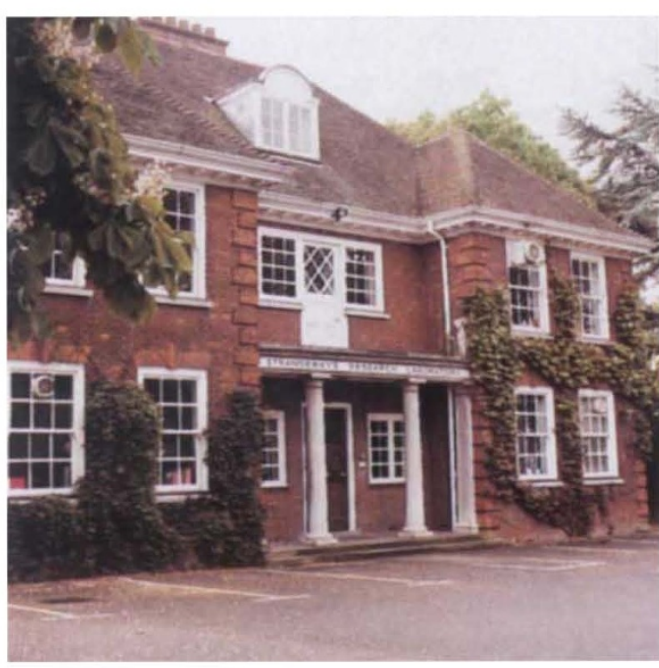

Strangeways laboratory in research row.

change in its scientific priorities.

The trustees of the Strangeways Research Laboratory in Cambridge, perhaps best known for its early pioneering work on tissue and organ culture, want to move into the field of inflammation research to broaden the laboratory's base and strengthen its links with the University of Cambridge. But senior scientists, many of whom are already being required to relocate their research teams as a result of their disagreement with the trustees, say that they have been excluded from discussions on the laboratory's future, and they have little confidence in what has been presented.

Opponents see the shift as a takeover by the university medical school, which is keen to strengthen its position in clinical research. The school suffers from an acute shortage of space at its Addenbrooke's Hospital site, which is five minutes from the Strangeways.

The crisis at Strangeways has been triggered by the forthcoming retirement in September of its current director, John Dingle, and the choice as his successor of Peter Lachmann, professor of immunology at the university, honorary director of the Molecular Immunopathology Laboratory of the Medical Research Council (MRC) and president of the Royal College of Pathologists. The trustees have endorsed Lachmann's proposal to concentrate on the mechanisms of inflammation and one of the laboratory's governors, Keith Peters, regius professor of physic (medicine) at the medical school, says that he would eventually like to see the laboratory become an institute for the study of such problems.

The chairman of the trustees, Sir Barry Cross, says that the laboratory intends to ask the MRC to support a major programme on inflammation research. The council is the main financial supporter of the Strangeways laboratory which, apart from its land and buildings, lacks a significant endowment.

The other three trustees are John Bradfield, the bursar of Trinity College, Cambridge; Lord Butterfield (Peters' predecessor at the medical school); and Sir Andrew Huxley, a former president of the Royal Society. They point out that the secretary of the MRC, Dai Rees, has already told them that the laboratory must demonstrate that it can "enhance the prospect of [achieving] far-reaching conceptual advances in biomedical science" if it hopes to continue receiving substantial MRC support.

Laboratory staff dispute this conclusion, saying that it is at odds with a recent outside review that gave it alpha-plus ratings and with the MRC's renewal of five-year grants for two of its three main research groups. Others say that the staff is hobbled by the perception that connective tissue research is less fashionable than research on more visible diseases.

Senior staff who disagree with the scientific content of Lachmann's plans have been
Basel. Switzerland is easing its historic restrictions on foreign workers, making it easier for researchers to get a Swiss work permit and to leave the country temporarily. One measure of success will be the extent to which research institutes will be able to recruit technical staff from abroad.

The changes loosen decades of restrictive policies on foreign industrial workers, under which each of the country's 26 cantons are allotted a certain number of permits and employers have to prove - through advertisements - that no Swiss national is qualified for the job. But facing a deepening recession, Switzerland decided that, according to a government spokesman, "restriction in the exchange of people might hamper recovery". Last autumn Swiss voters passed a referendum delaying membership in the European Economic Area (EAA) (see Nature 363, 8; 1993), and politicians have reacted by trying to show that Switzerland is "by no means an isolated island in Europe".

The new law, which went into effect on

told by the MRC that they must find other sites for their work. One group, headed by Jeremy Saklatvala, has already agreed to move to the Agricultural and Food Research Council Institute of Animal Physiology and Genetics Research in the nearby village of Babraham.

In all, more than 40 scientists and technical staff (out of a laboratory total of about 80 ) will have to move. The MRC says that no decision on the future of Strangeways will be made until it receives detailed research plans from Lachmann.

Strangeways staff have asked colleagues around the world to help them to block the trustees' plans. Last week, the trustees wrote to the authors of more than 70 letters that they have received, saying that they are doing their utmost to ensure a successful future for the laboratory. "Closure of the laboratory, or fundamental changes in its status, are options that we would consider only if we do not succeed in finding a way forward for it as an independent institution", the trustees explained.

The trustees and Lachmann have made it clear that they will not back away from their proposed changes in the scientific priorities of the laboratory. But many supporters of the current research programme fear that the damage has already been done.

"One of the present strengths of Strangeways is that the research group leaders have overlapping interests", says Roger Mason, professor of biochemistry at the Charing Cross and Westminster Medical School in London and chairman of the British Connective Tissue Society. "If these groups all start disappearing to other institutions, the critical mass will have been lost."

David Dickson

\title{
Swiss loosen restrictions on foreign workers
}

1 May, does not increase the quota of foreigners, but it eliminates the requirement to advertise vacancies locally. It also allows foreigners to leave the country to take courses without having to reapply for a work permit.

The changes are welcomed by the chemical and pharmaceutical industries, which make up 21 per cent of the Swiss economy. "The new regulations make recruitment of personnel much easier", says Heiko Jürgensen of Ciba-Geigy.

Many of the 10,000 foreign scientists working in Switzerland are employed by Basel's 'big three' pharmaceutical companies - Ciba-Geigy, Sandoz and HoffmannLa Roche - and commute to work from France and Germany. Basel and other cantons close to the borders have special quotas that allow for additional Grenzgänger (border crossers).

Although these restrictions have never applied to academics, laws such as a ban on buying property make life uncomfortable for foreigners. And officials are always looking for violators.

Oliver Klaffke 